\title{
TSPphg Lysin from the Extremophilic Thermus Bacteriophage TSP4 as a Potential Antimicrobial Agent against Both Gram-Negative and Gram-Positive Pathogenic Bacteria
}

\author{
Feng Wang ${ }^{1,+}$, Xinyu Ji ${ }^{1,+}$, Qiupeng Li ${ }^{1}$, Guanling Zhang ${ }^{1}$, Jiani Peng ${ }^{1}$, Jun Hai ${ }^{1}$, Yao Zhang ${ }^{1}$, \\ Baiquan $\mathrm{Ci}^{1}{ }^{1}$, Hongwei $\mathrm{Li}^{1}{ }^{1}$, Yan Xiong ${ }^{1}$, Xianyu Deng ${ }^{1}$ and Lianbing Lin ${ }^{1,2, *}$ \\ 1 Faculty of Life Science and Technology, Kunming University of Science and Technology, 727 South Jingming \\ Road, Kunming 650500, China; wangfeng076@hotmail.com (F.W.); jixinyu@stu.kust.edu.cn (X.J.); \\ liqiupeng66@hotmail.com (Q.L.); zhangguanling@stu.kust.edu.cn (G.Z.); pengjiani@stu.kust.edu.cn (J.P.); \\ hj1825394672@hotmail.com (J.H.); zyao@stu.kust.edu.cn (Y.Z.); cibq@stu.kust.edu.cn (B.C.); \\ lihongwei667@hotmail.com (H.L.); xiongyan@stu.kust.edu.cn (Y.X.); dengxy@kust.edu.cn (X.D.) \\ 2 Engineering Research Center for Replacement Technology of Feed Antibiotics of Yunnan College, 727 South \\ Jingming Road, Kunming 650500, China \\ * Correspondence: linlb@kmust.edu.cn; Tel.: +86-139-8768-1986; Fax: +86-871-6592-0570 \\ + These authors contributed equally to this work.
}

Received: 9 December 2019; Accepted: 7 February 2020; Published: 9 February 2020

\begin{abstract}
New strategies against antibiotic-resistant bacterial pathogens are urgently needed but are not within reach. Here, we present in vitro and in vivo antimicrobial activity of TSPphg, a novel phage lysin identified from extremophilic Thermus phage TSP4 by sequencing its whole genome. By breaking down the bacterial cells, TSPphg is able to cause bacteria destruction and has shown bactericidal activity against both Gram-negative and Gram-positive pathogenic bacteria, especially antibiotic-resistant strains of Klebsiella pneumoniae, in which the complete elimination and highest reduction in bacterial counts by greater than 6 logs were observed upon $50 \mu \mathrm{g} / \mathrm{mL}$ TSPphg treatment at $37^{\circ} \mathrm{C}$ for $1 \mathrm{~h}$. A murine skin infection model further confirmed the in vivo efficacy of TSPphg in removing a highly dangerous and multidrug-resistant Staphylococcus aureus from skin damage and in accelerating wound closure. Together, our findings may offer a therapeutic alternative to help fight bacterial infections in the current age of mounting antibiotic resistance, and to shed light on bacteriophage-based strategies to develop novel anti-infectives.
\end{abstract}

Keywords: bacteriophage; endolysin; thermostable lytic protein; antibiotic-resistant bacteria; antimicrobial drug; Staphylococcus aureus; skin infection

\section{Introduction}

Currently, bacterial resistance has been reported in all WHO regions and identified for every antimicrobial drug developed to date [1,2]. In particular, the recent increase in bacterial strains showing resistance to almost all classes of antibiotics commonly used in human medicine has become a serious threat to public health worldwide $[3,4]$. Therefore, there is an urgent need to develop alternatives to conventional antibiotics for use in the treatment of infectious diseases.

Bacteriophages (also termed phages) have been found to be natural agents fighting against bacterial infections in the early part of the 20th century, and they have showed plenty of advantages in controlling infections in a wide range of experimental animal models such as chickens and cattle [5-7]. In fact, the emergence of a phage technology revolution is not just limited to whole phages. Recently, 
their lytic enzymes (also known as lysins), which can degrade peptidoglycan and thus digest a host's bacterial cell wall, have also gained new ground as promising antibacterial agents due to their safety, broad substrate spectrum and low possibility of developing resistance [8-10]. When applied exogenously in the treatment of bacterial infections, recombinant phage lysins can exhibit similarly effective antibacterial performance to their native counterparts, supporting the wide application of these agents in the fields of biotechnology, medicine, food and agriculture [11,12]. Interestingly, lysins can also evolve with time based on the needs of phages to release from their infected hosts [13].

In the present study, we sequenced the whole genome of an extremophilic Thermus phage TSP4 that was isolated from Tengchong hot spring in Yunnan Province of China at a temperature of $70^{\circ} \mathrm{C}$ with a $\mathrm{pH}$ of 7.0 [14], which is particularly interesting because of the thermostability of its lytic proteins and nucleotide metabolism system. In the process, we identified a novel phage lysin named TSPphg and assessed its in vitro and in vivo antibacterial activity against a panel of antibiotic-resistant strains.

\section{Materials and Methods}

\subsection{Ethics Statement}

The experimental mice (Kunming mice) were purchased from the Animal Center of Kunming Medical University (Kunming, China). All procedures were conducted in accordance with the Regulations for the Administration of Affairs Concerning Experimental Animals, and approved by the Animal Research Ethics Committee of Faculty of Life Science and Technology, Kunming University of Science and technology on 15 May 2019 (document no. 2019-LBL-001).

\subsection{Bacterial Strains and Culture Conditions}

Strains of Escherichia coli, Salmonella paratyphi B and Bacillus subtilis were cultivated at $37^{\circ} \mathrm{C}$ with shaking (150 rpm) in Luria Broth (LB) medium (10 g/L tryptone, $10 \mathrm{~g} / \mathrm{L}$ yeast extract, $5 \mathrm{~g} / \mathrm{L} \mathrm{NaCl}, \mathrm{pH}=7.2$ \pm 0.2). Staphylococcus epidermidis, Micrococcus luteus and Staphylococcus aureus strains were grown with shaking at $150 \mathrm{rpm}$ in Nutrient Agar medium $(10 \mathrm{~g} / \mathrm{L}$ tryptone, $3 \mathrm{~g} / \mathrm{L}$ beef extract, $5 \mathrm{~g} / \mathrm{L} \mathrm{NaCl}, \mathrm{pH}=7.2 \pm$ $0.2)$ at $37{ }^{\circ} \mathrm{C}$, and clinical isolates of Klebsiella pneumoniae were cultured at $37^{\circ} \mathrm{C}$ in Brain Heart Infusion (BHI) medium (10 g/L tryptone, $12.5 \mathrm{~g} / \mathrm{L}$ brain infusion powder, $5 \mathrm{~g} / \mathrm{L}$ beef heart powder, $5 \mathrm{~g} / \mathrm{L} \mathrm{NaCl}, 2$ $\mathrm{g} / \mathrm{L}$ glucose, $2.5 \mathrm{~g} / \mathrm{L} \mathrm{Na}_{2} \mathrm{HPO}_{4}, \mathrm{pH}=7.4 \pm 0.2$ ) with shaking at $150 \mathrm{rpm}$. Thermus sp. TC4 that belongs to the genus Thermus was grown at $60^{\circ} \mathrm{C}$ on DSM88 medium with shaking as previously reported [14]. The bacteria used as substrates for TSPphg were purchased from the American Type Culture Collection (S. aureus ATCC6538, S. epidermidis ATCC12228 and M. luteus ATCC4698) or National Center for Medical Culture Collections (S. paratyphi B CMCC(B)50094 and B. subtilis CMCC(B)63501). The nine different isolates of K. pneumoniae (see Table 1), a multidrug-resistant S. aureus strain (1606BL1486) and E. coli O157 (KUST401) were kindly provided by Prof. Xueshan Xia and Prof. Yuzhu Song in the Research Center of Molecular Medicine of Yunnan Province, Kunming University of Science and Technology, with their antibiotic resistance patterns determined based on susceptibility tests according to the CLSI (Clinical and Laboratory Standards Institute) guidelines. All other bacteria were stored in our laboratory. E. coli strains DH5a and BL21 were used for plasmid construction and recombinant protein overproduction, respectively. When necessary, the media were supplemented with ampicillin at $100 \mu \mathrm{g} / \mathrm{mL}$ or kanamycin at $50 \mu \mathrm{g} / \mathrm{mL}$. All strains were stored at $-80^{\circ} \mathrm{C}$.

\subsection{Genome Sequencing and Annotation}

The genomic DNA of phage TSP4 was extracted and purified by a DNA extraction kit (Omega Bio-tek Inc., Norcross, GA, USA) and sequenced in shanghai majorbio company by Sanger sequencing. Open reading frames (ORFs) were predicted with ORF finder on the NCBI website (https://www.ncbi. nlm.nih.gov/orffinder). All ORF predictions were refined by blasting ORFs to the NCBI database. The conserved domain analysis was carried out based on the NCBI Conserved Domain Database 
(CDD v3.17, last update: 2019-04-03). This genome project has been deposited in GenBank under the accession number MH992131.1.

\subsection{Production and Purification of Recombinant Protein TSPphg}

The highly efficient expression of TSPphg in the host E. coli BL21 cells and its rapid purification using the special thermolysis method were already described in detail in our previous publication [15]. Briefly, TSPphg gene was amplified by PCR with gene-specific primers from the phage TSP4 genome (forward: 5'-CATGCCATGGCAATGCGTCTACCGACTAAGAC-3' and reverse: 5'-CCGCTCGAGTTTACCTCCTAGCAACTTGG-3'). The 5' ends of forward and reverse primers contained NcoI and XhoI restriction sites (underlined), respectively. The modified primers were used to amplify the TSPphg gene for directional cloning into the expression vector pET-28a. The PCR program was performed as follows: initial denaturation at $94^{\circ} \mathrm{C}$ for $3 \mathrm{~min}$, followed by 30 cycles of $94^{\circ} \mathrm{C}$ for $45 \mathrm{~s}$, $58^{\circ} \mathrm{C}$ for $30 \mathrm{~s}$, and $72{ }^{\circ} \mathrm{C}$ for $90 \mathrm{~s}$. E. coli BL21 cells harboring the pET-28a-TSPphg vector were then used as the host for recombinant protein expression. Lactose $(1 \mathrm{~g} / \mathrm{L})$ was used for induction to overproduce the phage lysin TSPphg. After induction, cell pellets were collected by centrifuging at $12,000 \mathrm{~g}$ for $10 \mathrm{~min}$ at $4{ }^{\circ} \mathrm{C}$, then resuspended in phosphate-buffered saline (PBS) containing $137 \mathrm{mM} \mathrm{NaCl}, 2.7 \mathrm{mM}$ $\mathrm{KCl}, 4.3 \mathrm{mM} \mathrm{Na}_{2} \mathrm{HPO}_{4}$, and $1.4 \mathrm{mM} \mathrm{KH}_{2} \mathrm{PO}_{4}$ with a $\mathrm{pH}$ of 7.4. The recovery of thermostable TSPphg protein was performed by a direct heat treatment at $55^{\circ} \mathrm{C}$ for $30 \mathrm{~min}$ to precipitate unstable host proteins. Subsequently, the samples were centrifuged at $12,000 \times \mathrm{g}$ for $10 \mathrm{~min}$ to pellet debris, and filtered using 0.22- $\mu \mathrm{m}$ pore-size filters (Sartorius, Ulm, Germany). The final purified TSPphg dissolved in PBS was confirmed by $12 \%$ sodium dodecyl sulfate polyacrylamide gel electrophoresis (SDS-PAGE). Finally, from $1 \mathrm{~L}$ of the host $E$. coli BL21 culture we could obtain approximately $79 \mathrm{mg}$ of TSPphg.

\subsection{Assessing Thermostability of TSPphg and Effects of $\mathrm{pH}, \mathrm{NaCl}$ and EDTA on Its Activity}

To evaluate the characteristics of TSPphg, the host bacterium for phage TSP4, Thermus sp. TC4 (GenBank accession: GQ853550.1) was used as the substrate and cultured in DSM88 medium at $60{ }^{\circ} \mathrm{C}$ until an $\mathrm{OD}_{600}$ of 0.4-0.5 was reached as previously described [14]. Then, the bacterial cells were collected by centrifuging at $1000 \times \mathrm{g}$ for $10 \mathrm{~min}$ at $4{ }^{\circ} \mathrm{C}$, washed twice, then resuspended in PBS $(137 \mathrm{mM}$ $\mathrm{NaCl}, 2.7 \mathrm{mM} \mathrm{KCl}, 4.3 \mathrm{mM} \mathrm{Na}_{2} \mathrm{HPO}_{4}, 1.4 \mathrm{mM} \mathrm{KH}_{2} \mathrm{PO}_{4}, \mathrm{pH}$ 7.4). For thermostability assays, TSPphg at $50 \mu \mathrm{g} / \mathrm{mL}$ prepared in PBS was first heated at different temperatures (from 10 to $85^{\circ} \mathrm{C}$ ) for $30 \mathrm{~min}$; then, its lytic activity was measured by the standard turbidity reduction assay against $10^{8}$ of Thermus sp. TC4 cells at $60^{\circ} \mathrm{C}$ in a standard 96-well microtiter plate (ShenYing Biotechnology, Haimeng, China). The lytic activity of TSPphg was determined by a decrease in $\mathrm{OD}_{600}$ in a plate reader (Wisdom Applied Science, mode 6500, Newark, DE, USA), and all plates were shaken for $4 \mathrm{~s}$ before each measurement. To study the effects of different $\mathrm{pH}$ values and $\mathrm{NaCl}$ concentrations on the activity of TSPphg, exponential phases of Thermus sp. TC4 cells $\left(\mathrm{OD}_{600}=0.4-0.5\right)$ were exposed to $50 \mu \mathrm{g} / \mathrm{mL}$ of TSPphg at $60^{\circ} \mathrm{C}$ for $1 \mathrm{~h}$ over a range of $\mathrm{pH}$ values ( 4 to 10) or $\mathrm{NaCl}$ concentrations (from 0 to $1000 \mathrm{mM}$ ) [16]. Lysis of TC4 cells by TSPphg was also monitored in the absence (non-treated control) or in the presence of ethylenediaminetetraacetic acid (EDTA, from 0.5 to $5 \mathrm{mM}$ ). For all experiments, control wells were run in parallel, and the lytic activity of TSPphg was calculated at specific condition as follows: $\left(\mathrm{OD}_{600}\right.$ (buffer only) - $\mathrm{OD}_{600}$ sample (lysin added))/initial $\mathrm{OD}_{600}$, as previously described $[17,18]$. All assays were repeated in triplicate.

\subsection{In Vitro Antibacterial Activity Assays}

To examine the antibacterial activity of TSPphg, various Gram-negative or Gram-positive bacteria were grown and tested as described previously [19]. Briefly, the bacteria were grown at $37^{\circ} \mathrm{C}$ in a rotary shaker at $150 \mathrm{rpm}$ until an $\mathrm{OD}_{600}$ of $0.6-0.8$ was reached, then centrifuged at $1000 \mathrm{~g}$ for $10 \mathrm{~min}$ at $4{ }^{\circ} \mathrm{C}$, washed twice, and resuspended in PBS containing $137 \mathrm{mM} \mathrm{NaCl}, 2.7 \mathrm{mM} \mathrm{KCl}, 4.3 \mathrm{mM} \mathrm{Na}_{2} \mathrm{HPO}_{4}$, and $1.4 \mathrm{mM} \mathrm{KH}_{2} \mathrm{PO}_{4}$ at a $\mathrm{pH}$ of 7.4. For time-kill curve experiments, approximately $10^{7} \mathrm{CFU} / \mathrm{mL}$ of bacterial cells were treated with increasing concentrations of TSPphg $(17,34$, and $68 \mu \mathrm{g} / \mathrm{mL})$ in PBS (pH 7.4) 
that was chosen based on an analysis of the effects of different $\mathrm{pH}$ values and $\mathrm{NaCl}$ concentrations on the activity of TSPphg. After incubation at $37^{\circ} \mathrm{C}$ and $150 \mathrm{rpm}$ for 0 to $90 \mathrm{~min}$ (samples were taken at an interval of $10 \mathrm{~min}$ ), aliquots were serially diluted and spread onto LB agar plates. Subsequently, viable cells and $\log$ kills at different time points were evaluated after overnight incubation at $37^{\circ} \mathrm{C}$. The experiments were repeated thrice. To assess the antibacterial spectrum of TSPphg (see Table 1), a panel of Gram-negative and Gram-positive bacteria (from $10^{5}$ to $10^{8} \mathrm{CFU} / \mathrm{mL}$ ) were mixed with $50 \mu \mathrm{g}$ of TSPphg dissolved in PBS to make a final volume of $1 \mathrm{~mL}$ and a final concentration of $2.6 \mu \mathrm{M}$. The mixtures were then incubated at $37^{\circ} \mathrm{C}$ for $1 \mathrm{~h}$, and the viable cell numbers were counted by plating on agar plates. The antimicrobial activity of TSPphg was calculated as a relative decrease in logarithmic units after the indicated time points as follows: $\log _{10}\left(\mathrm{~N}_{0} / \mathrm{N}_{\mathrm{i}}\right), \mathrm{N}_{0}=$ number of untreated cells (in the control) and $\mathrm{N}_{\mathrm{i}}=$ number of cells counted after treatment $[17,18]$. All assays were performed with at least three biological replicates. The limit of detection for bacterial counts in agar plate was 10 colony-forming units (CFU)/mL in this study.

\subsection{Mouse Model of Skin Damage and TSPphg Treatment}

A mouse model of skin damage was established using the female Kunming mice according to the methods described in previous studies [20,21]. Briefly, the hair on an approx. $2 \mathrm{~cm}^{2}$ section of the dorsum of each mouse was shaved and cleansed with $70 \%$ alcohol, then the epidermis was stripped using autoclave tape to induce skin damage. The damaged skin was topically colonized with the multidrug-resistant $S$. aureus (strain No. 1606BL1486) by using $20 \mu \mathrm{L}\left(1 \times 10^{5} \mathrm{CFU}\right)$ cultures suspended in PBS. All mice were housed individually to avoid cross-infection and traumatic damage to the wounds by other animals. After $24 \mathrm{~h}$ of colonization, $100 \mu \mathrm{L}$ of $50 \mu \mathrm{g} / \mathrm{mL}$ TSPphg dissolved in PBS or $100 \mu \mathrm{L}$ of $50 \mu \mathrm{g} / \mathrm{mL}$ kanamycin were applied to the wounds, with $100 \mu \mathrm{L}$ PBS as the negative control. All mice were treated once a day with TSPphg, kanamycin or PBS for seven days, and the wounds were photographed after treatment at different time points ( $n=4$ mice per group per experiment). Subsequently, the percentage of wound healing was calculated, and the bacterial loads in skin wounds were evaluated by serial dilution and plating on LB agar plates [22].

\subsection{Scanning Electron Microscope (SEM) Analysis}

The effects of exogenous TSPphg treatment on bacterial cell lysis were analyzed using a scanning electron microscope (Quanta 200, FEI, Holland) as previously described [22]. In brief, the bacteria were grown at $37^{\circ} \mathrm{C}$ until an $\mathrm{OD}_{600}$ of $0.6-0.8$ was reached, then they were collected by centrifugation at $1000 \mathrm{~g}$ for $5 \mathrm{~min}$ at $4^{\circ} \mathrm{C}$ and washed twice with PBS; finally, $10^{5} \mathrm{CFU} / \mathrm{mL}$ of bacterial cells were incubated with $50 \mu \mathrm{g} / \mathrm{mL}$ TSPphg and dissolved in PBS at $37^{\circ} \mathrm{C}$ for $1 \mathrm{~h}$. Subsequently, the bacterial lysates were fixed with $2.5 \%$ glutaraldehyde at $4{ }^{\circ} \mathrm{C}$ for $6 \mathrm{~h}$ and dehydrated in a graded ethanol series $(30 \%, 50 \%, 60 \%, 70 \%, 80 \%$, and $90 \%)$ for 20 min each time. The samples were further dried at room temperature for $24 \mathrm{~h}$, then used for SEM analysis according to the manufacturer's instructions.

\subsection{Statistical Analysis}

Statistical differences of quantitative data were determined by a Student's $t$-test (between two groups) or a one-way analysis of variance (ANOVA, among three or more groups) followed by a Bonferroni correction using the $\mathrm{R}$ software version 3.2.2. All data were expressed as mean \pm standard deviation (SD) of $n=3$ independent replicates. The two-tailed $p$ value $<0.05$ was considered statistically significant.

\subsection{Nucleotide and Protein Sequence Accession Number}

The complete genome sequence of Thermus phage TSP4 and protein sequence of TSPphg lysin were deposited at GenBank under the accession numbers MH992131.1 and QAY18185.1, respectively. 


\section{Results}

\subsection{Identification of TSPphg by Sequencing and Annotation of Phage TSP4 Genome}

Previously, we isolated and characterized a Thermus phage named TSP4 from the Tengchong hot spring in China, and the host bacterium for phage TSP4 was Thermus sp. TC4 (GenBank accession: GQ853550.1), which was found to be a Gram-negative, rod-shaped, aerobic thermophile thriving at $40-80{ }^{\circ} \mathrm{C}$ [14]. In this study, we further sequenced the complete genome of phage TSP4. As shown in Figure 1A, it comprises one circular chromosome of 83,142 bp with a $56 \%$ GC content. Bioinformatic analysis predicted 108 protein-coding genes but no rRNA or tRNA genes within the genome of TSP4 (GenBank accession number MH992131; Table S1). Among them, TSPphg was predicted to be a putative phage lysin containing a conserved M23 peptidase domain (NCBI domain architecture ID: 10480195). It is thought to be highly similar to the M23 peptidase family (accession ID: pfam01551), which comprises specific hydrolytic activity on bacterial peptidoglycans, and thus could result in lysis of bacterial cells (Figure 1B). The natural DNA sequence of the TSPphg gene in the phage TSP4 genome was cloned by PCR. Overexpression and rapid purification of heat-stable TSPphg protein from the host $E$. coli BL21 cells were previously described in our publication [15], and there is no difference in the sequence between recombinant and wild-type TSPphg lysin. The purified TSPphg lysin used in this study was confirmed by $12 \%$ SDS-PAGE (Figure 1C).
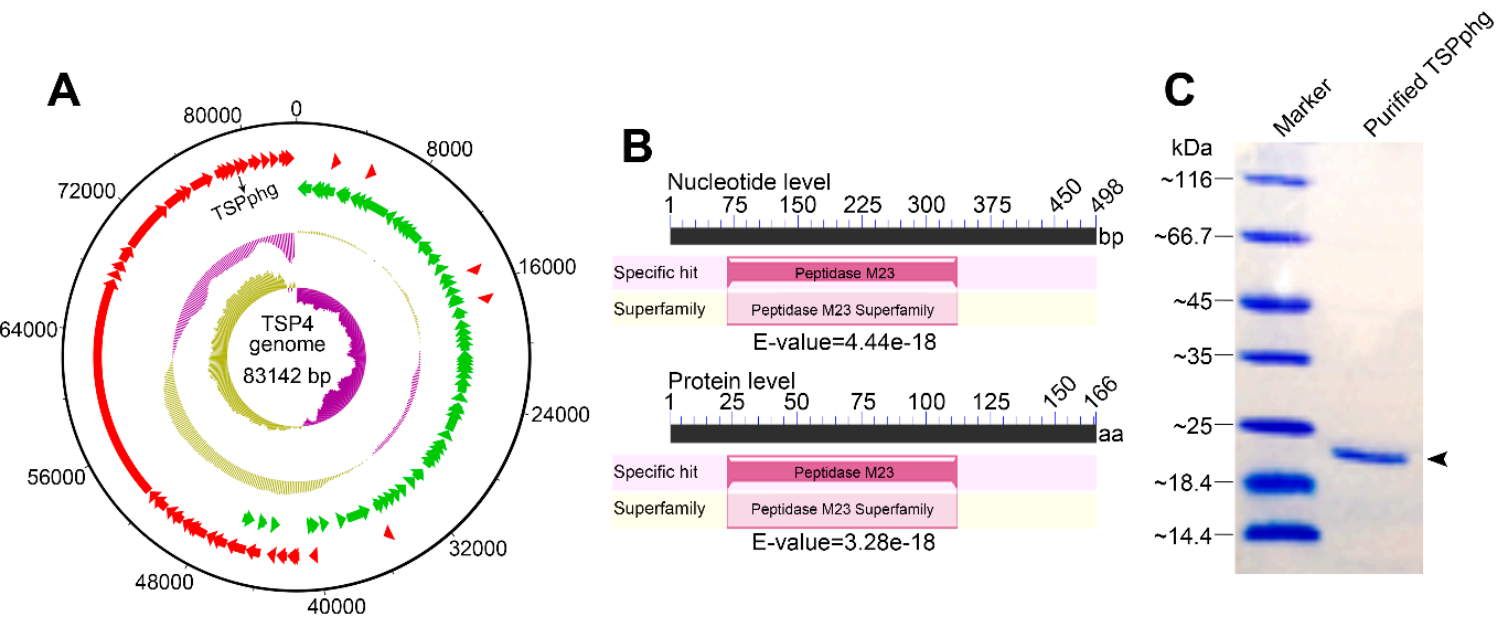

Figure 1. Identification of TSPphg by sequencing the complete genome sequence of Thermus phage TSP4. (A) Genome map of TSP4, from inside to outside: circle 1 displays the GC skew ((G-C)/(G+ C)); circle 2 shows the GC percentage plot; circles 3 and 4 denote the ORFs on the minus (' $\left.-^{\prime}\right)$ strand (green) and plus ('+') strand (red), respectively; circle 5 demonstrates the numbered scale with an interval of $4 \mathrm{~kb}$. (B) The conserved domain analysis of TSPphg at both nucleotide and protein levels. (C) SDS-PAGE analysis of the purified TSPphg in this study. The black arrowhead denotes the band of recombinant TSPphg lysin.

Next, the effects of $\mathrm{pH}$ and $\mathrm{NaCl}$ on the lytic activity of TSPphg against the host strain for phage TSP4, Thermus sp. TC4, were examined. The $\mathrm{pH}$ range for TSPphg was measured from $\mathrm{pH} 4.0$ to 10.0 and the highest activity was observed at pH 8.0 (Figure S1A). Based on this data, further examination of $\mathrm{NaCl}$ concentration dependence was performed at $\mathrm{pH}$ 8.0. As shown in Figure S1B, we found that TSPphg displayed optimal activity at $100 \mathrm{mM} \mathrm{NaCl}$, making it more attractive for applications in physiological conditions where the $\mathrm{NaCl}$ concentration is $130 \mathrm{mM}[17,23]$. Unexpectedly, the addition of EDTA did not have enhanced effect on the activity of TSPphg (Figure S2), which is in line with PlyE146, a phage lysin comprising a highly positively charged C-terminal domain [24]. Based on these results, the common phosphate-buffered saline (PBS), which is a balanced salt solution with similar physiological conditions, was used as the working buffer for TSPphg for the following antibacterial 
assays, unless otherwise stated. Moreover, the thermostability of TSPphg was tested in a range of temperatures from 10 to $85^{\circ} \mathrm{C}$. As shown in Figure S3, TSPphg maintained more than $90 \%$ activity after a $30 \mathrm{~min}$ heat treatment between 40 and $70{ }^{\circ} \mathrm{C}$, suggesting its resistance to denaturation at high temperatures.

\subsection{Bactericidal Activity of TSPphg against both Gram-negative and Gram-positive Bacteria}

Further, we carried out dose-dependent experiments and measured the antimicrobial activity of TSPphg against both Gram-negative (S. paratyphi B, E. coli O157 and K. pneumoniae) and Gram-positive (B. subtilis and S. aureus) bacteria at $37^{\circ} \mathrm{C}$ in vitro. It can be seen from Figure 2 that the bactericidal activity of the TSPphg increased proportionally to its concentration, and it showed antimicrobial effects on both Gram-negative (Figure 2A-C) and Gram-positive bacterial strains (Figure 2D,E). It is noteworthy that with the concentration of $68 \mu \mathrm{g} / \mathrm{mL}$, incubation of TSPphg with different bacterial cell suspensions for $1.5 \mathrm{~h}$ can result in significant reduction in the bacterial counts by $6.61 \pm 0.19,6.57 \pm$ $0.19,7.07 \pm 0.01,3.92 \pm 0.37$, and $5.06 \pm 0.48 \operatorname{logs}$ for $S$. paratyphi B, E. coli O157, K. pneumoniae, B. subtilis and $S$. aureus, respectively ( $p=4.49 \mathrm{E}-07,4.94 \mathrm{E}-07,3.81 \mathrm{E}-12,5.12 \mathrm{E}-05$ and 5.27E-05 for TSPphg vs the PBS-treated control in the strains of S. paratyphi B, E. coli O157, K. pneumoniae, B. subtilis and S. aureus, respectively). Overall, these results suggest the potential of TSPphg for antimicrobial applications in biotechnology.
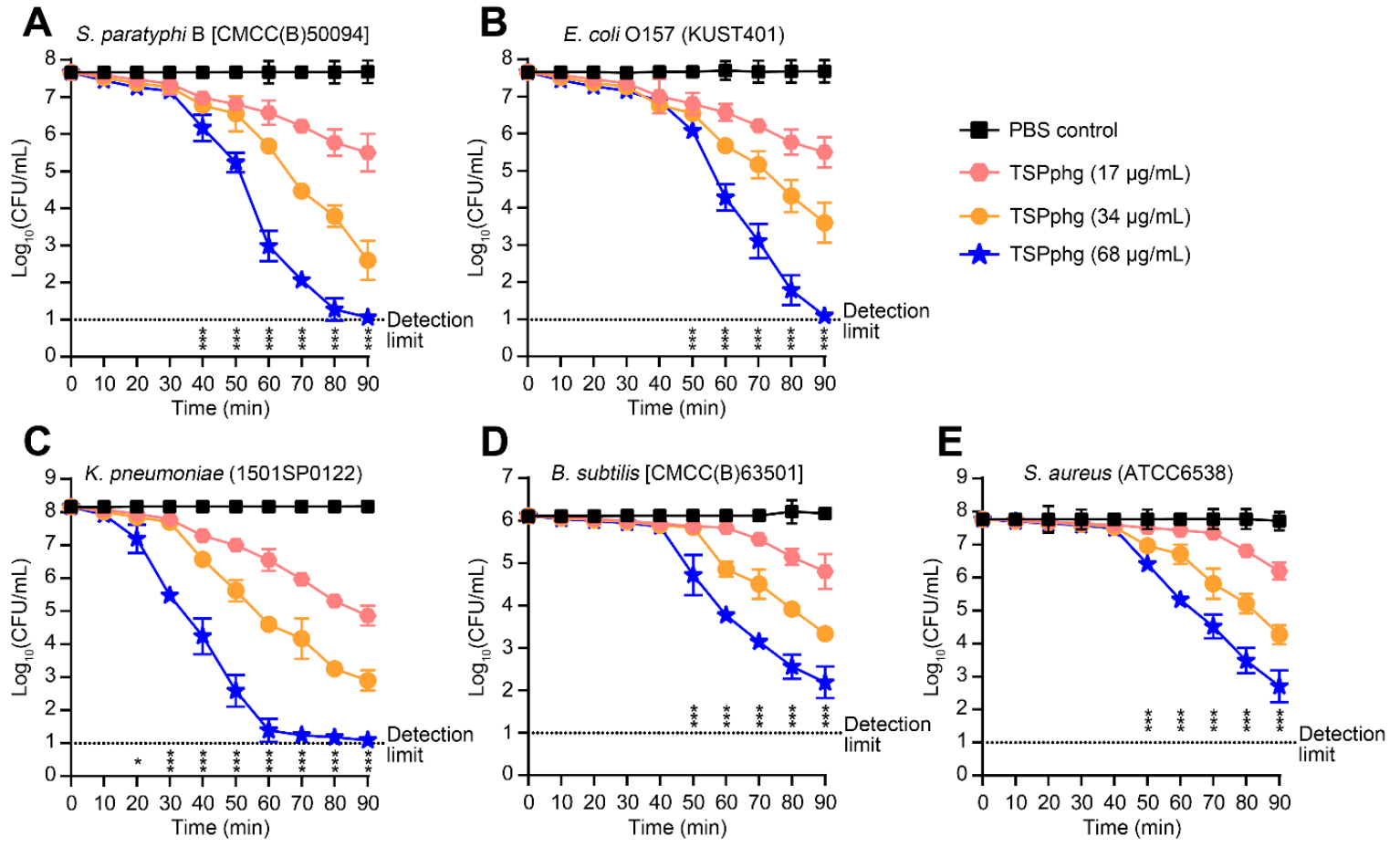

Figure 2. Time-kill assays. Antimicrobial activity of TSPphg against Salmonella paratyphi B (A), Escherichia coli $\mathrm{O} 157$ (B), Klebsiella pneumoniae (C), Bacillus subtilis (D) and Staphylococcus aureus (E). S. paratyphi B, E. coli $\mathrm{O} 157$ and K. pneumoniae are Gram-negative bacteria while B. subtilis and S. aureus are Gram-positive bacteria. Bacterial cell numbers were counted as $\log _{10}(\mathrm{CFU} / \mathrm{mL})$ at different time points as denoted. CFU means colony-forming unit. Data were presented as mean \pm standard deviation $(n=3)$ and were analyzed using one-way analysis of variance (ANOVA) with a Bonferroni correction. ${ }^{*}, p<0.05 ;{ }^{* * *}, p<$ 0.001 . The dotted line shows the limit of detection $(<10 \mathrm{CFU} / \mathrm{mL})$.

\subsection{Antibacterial Activity of TSPphg against Antibiotic-Resistant Strains of Klebsiella Pneumoniae}

It is well known that K. pneumoniae is a common cause of severe infections including pneumonia, endophthalmitis and meningitis [25]. Because of its hypervirulence and general occurrence of resistance 
to most antibiotics, in recent years infections caused by K. pneumoniae have become progressively difficult to treat $[26,27]$. In this study, we examined the antibacterial activity of TSPphg against nine different antibiotic-resistant strains of K. pneumoniae that are exceedingly hard to deal with in clinic practice. As shown in Table 1, TSPphg exhibited bactericidal activity against all these strains with a log reduction in bacterial counts between 1 and $>6$ logs. Particularly, we even observed the complete eradication (no bacteria colony was observed in agar plate after treatment) of K. pneumoniae strains 13A14918, 14A0287, and 1412SP0200 (>6.48, >6.74, and >6.82 logs, respectively) upon exposure of these bacterial cells to TSPphg $(50 \mu \mathrm{g} / \mathrm{mL})$ at $37^{\circ} \mathrm{C}$ for $1 \mathrm{~h}$. Besides the antibacterial activity against these Gram-negative strains of K. pneumoniae, TSPphg also showed activity against several strains of Gram-positive bacteria (B. subtilis, S. epidermidis, M. luteus, and S. aureus). For example, as demonstrated in Table 1, considerable TSPphg lysin activity was observed in the case of a highly dangerous and multidrug-resistant Gram-positive S. aureus (strain No. 1606BL1486) by a log reduction of 2.96 \pm 0.43 .

Larpin et al. have reported that the in vitro bactericidal concentration of PlyE146, a novel phage lysin targeting Gram-negative bacteria, was $400 \mu \mathrm{g} / \mathrm{mL}$ (as defined by a $\geq 3 \log _{10}$ decrease in cell counts compared to that in the absence of lysin) [24]. Accordingly, as shown in Figure S4, we found that the bactericidal concentration of TSPphg was approximately in a range of 30-80 $\mu \mathrm{g} / \mathrm{mL}$. Compared with recent studies $[16,18,24,28]$, this concentration is at a relatively low level.

Table 1. Bactericidal activity of TSPphg against various strains of Gram-negative or Gram-positive bacteria.

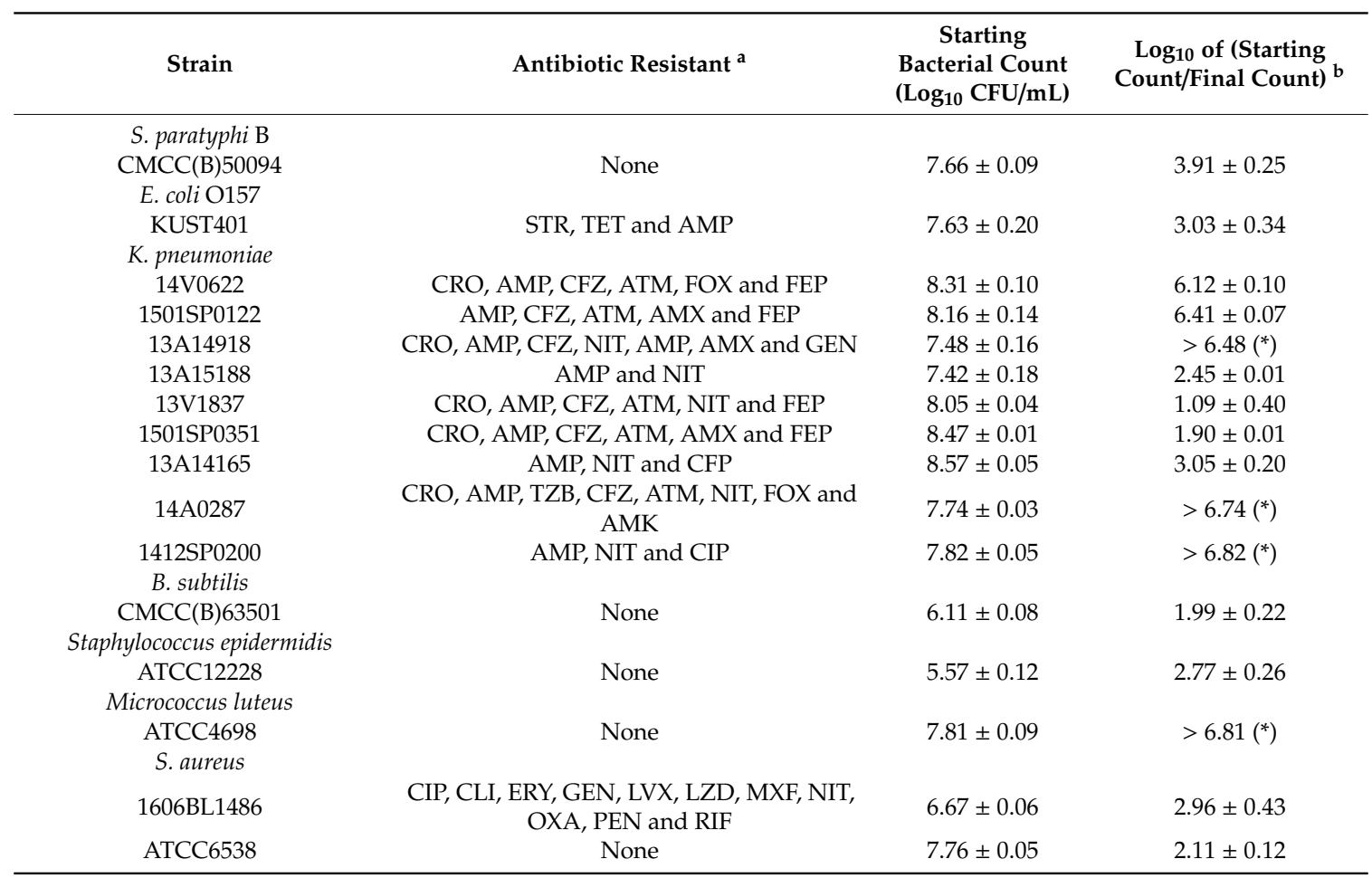

a STR, streptomycin; TET, tetracycline; AMP, ampicillin; CRO, ceftriaxone; CFZ, cefazolin; ATM, aztreonam; FOX, cefoxitin; FEP, cefepime; CFZ, cefazolin; AMX, amoxicillin; NIT, nitrofurantoin; GEN, gentamicin; CFP, cefoperazone; TZB, tazobactam; AMK, amikacin; CIP, ciprofloxacin; CLI, clindamycin; ERY, erythromycin; LVX, levofloxacin; LZD, linezolid; MXF, moxifloxacin; OXA, oxacillin; PEN, penicillin; RIF, rifampin. ${ }^{b}$ All values represent mean \pm standard deviation. For all tests, the log reduction for TSPphg treatment was measured after incubating different bacterial cells with $50 \mu \mathrm{g} / \mathrm{mL}$ TSPphg dissolved in PBS at $37^{\circ} \mathrm{C}$ for $1 \mathrm{~h}$, and three independent replicates were run in each reaction. The asterisks indicate that after TSPphg treatment, the number of viable cells was below the limit of detection $(<10 \mathrm{CFU} / \mathrm{mL})$.

\subsection{TSPphg Accelerates Wound Healing in a Murine Skin Infection Model}

To study the in vivo efficacy of TSPphg, we further established a mouse model of a 1606BL1486infected skin wound. When the shaved areas of Kunming mice were topically colonized with $20-\mu \mathrm{L}$ $\left(1 \times 10^{5} \mathrm{CFU}\right) 1606 \mathrm{BL} 1486$ cultures, the skin wound became red and swollen. After $24 \mathrm{~h}$ of bacterial 
challenge, the mice were daily treated with $100 \mu \mathrm{L}$ PBS, $100 \mu \mathrm{L}$ of $50 \mu \mathrm{g} / \mathrm{mL}$ kanamycin, or $100 \mu \mathrm{L}$ of $50 \mu \mathrm{g} / \mathrm{mL}$ TSPphg dissolved in PBS. As shown in Figure 3A,B, compared with groups of PBS-treated or no infection control, wound closure was considerably accelerated in both TSPphg and kanamycin treated groups. At day 7 , the infected wound areas shrank by $89 \pm 2.74 \%$ in the TSPphg group and $90 \pm 1.26 \%$ in the kanamycin group; both were significantly higher than the PBS-treated group ( $p=1.41 \mathrm{E}-04$ and 2.73E-05 for TSPphg vs the PBS-treated control, and kanamycin vs the PBS-treated control, respectively). However, there was no significant difference between TSPphg and kanamycin treatment $(p=0.60)$. Moreover, we found that after TSPphg treatment, the bacterial colony counts successfully decreased from the starting $5 \times 10^{6}$ to $55 \pm 9$ CFU/mL ( $p=6.93 \mathrm{E}-05$ for TSPphg vs the PBS-treated control, Figure $3 C$ ). These results suggest the in vivo efficacy of TSPphg in removing $S$. aureus from the skin damage and in accelerating wound closure, and warrant further exploration and optimization of its efficacy to develop TSPphg as a treatment option for drug-resistant bacterial infections in humans or poultry.

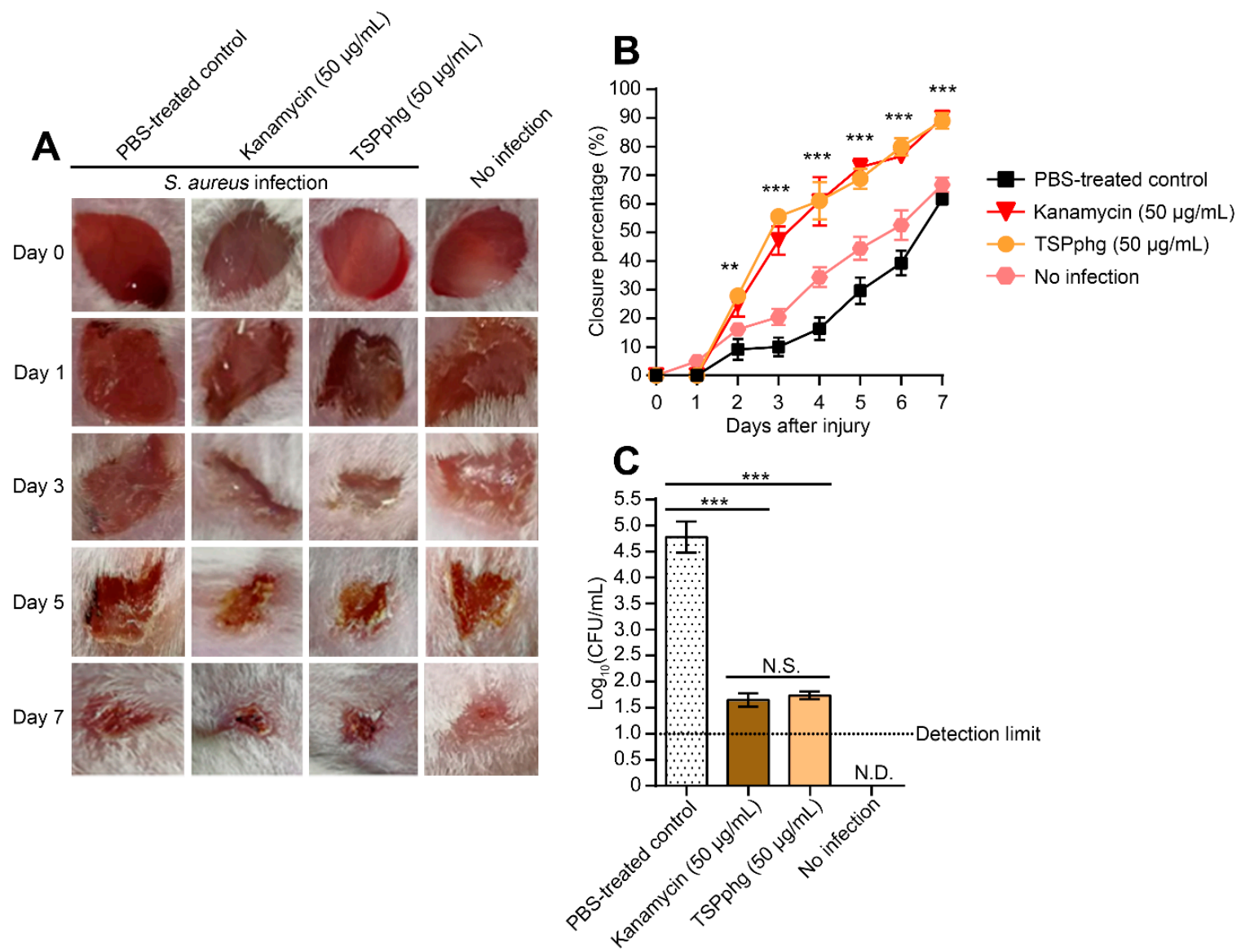

Figure 3. TSPphg promotes wound healing in a mouse model of a multidrug-resistant $S$. aureus-infected skin wound. (A) Photographs of the infected wound sites treated with $100 \mu \mathrm{L}$ PBS, $100 \mu \mathrm{L}$ of $50 \mu \mathrm{g} / \mathrm{mL}$ kanamycin, or $100 \mu \mathrm{L}$ of $50 \mu \mathrm{g} / \mathrm{mL}$ TSPphg, and the group without infection. (B) Wound healing percentage in all groups. Data were presented as mean \pm standard deviation $(n=4$ mice). $p$ values were calculated using one-way analysis of variance (ANOVA) with a Bonferroni correction. ${ }^{* *}, p<0.01$; ${ }^{* * *}, p<0.001$. (C) In vivo decolonization activity of TSPphg in experimental mice infected with multidrug-resistant $S$. aureus $\left(1 \times 10^{5} \mathrm{CFU} /\right.$ mouse). At $24 \mathrm{~h}$ after colonization, the mice were continuously treated once a day with $100 \mu \mathrm{L}$ PBS, $100 \mu \mathrm{L}$ of $50 \mu \mathrm{g} / \mathrm{mL}$ kanamycin or $100 \mu \mathrm{L}$ of $50 \mu \mathrm{g} / \mathrm{mL}$ TSPphg. At day 7 , the bacterial loads in the wounds were examined. Data were presented as mean \pm standard deviation of $n=4$ mice, and $p$ values were determined using a Student's $t$-test. ${ }^{* *}, p<0.001$; N.D., non-detectable; N.S., not significant $(p>0.05)$. 


\subsection{SEM Observations of the Bacteriolytic Activity of TSPphg}

To further investigate the detailed view of the bacterial cells after TSPphg treatment, scanning electron microscope (SEM) analysis was performed and the bacteriolytic activity of TSPphg against S. paratyphi B (CMCC(B)50094), E. coli O157 (KUST401), and S. aureus (ATCC6538) were tested. As shown in Figure 4, SEM of these strains upon exposure to $50 \mu \mathrm{g} / \mathrm{mL}$ TSPphg at $37^{\circ} \mathrm{C}$ for $1 \mathrm{~h}$ exhibited disrupted cells with extruding materials and cell debris, suggesting that exogenous TSPphg treatment could cause the destruction of bacteria and thus release of their intracellular components. These findings are consistent with the above-mentioned in vitro and in vivo antimicrobial activity of TSPphg, and further confirm its function as a phage lysin and thus as a promising phage-derived antimicrobial agent.

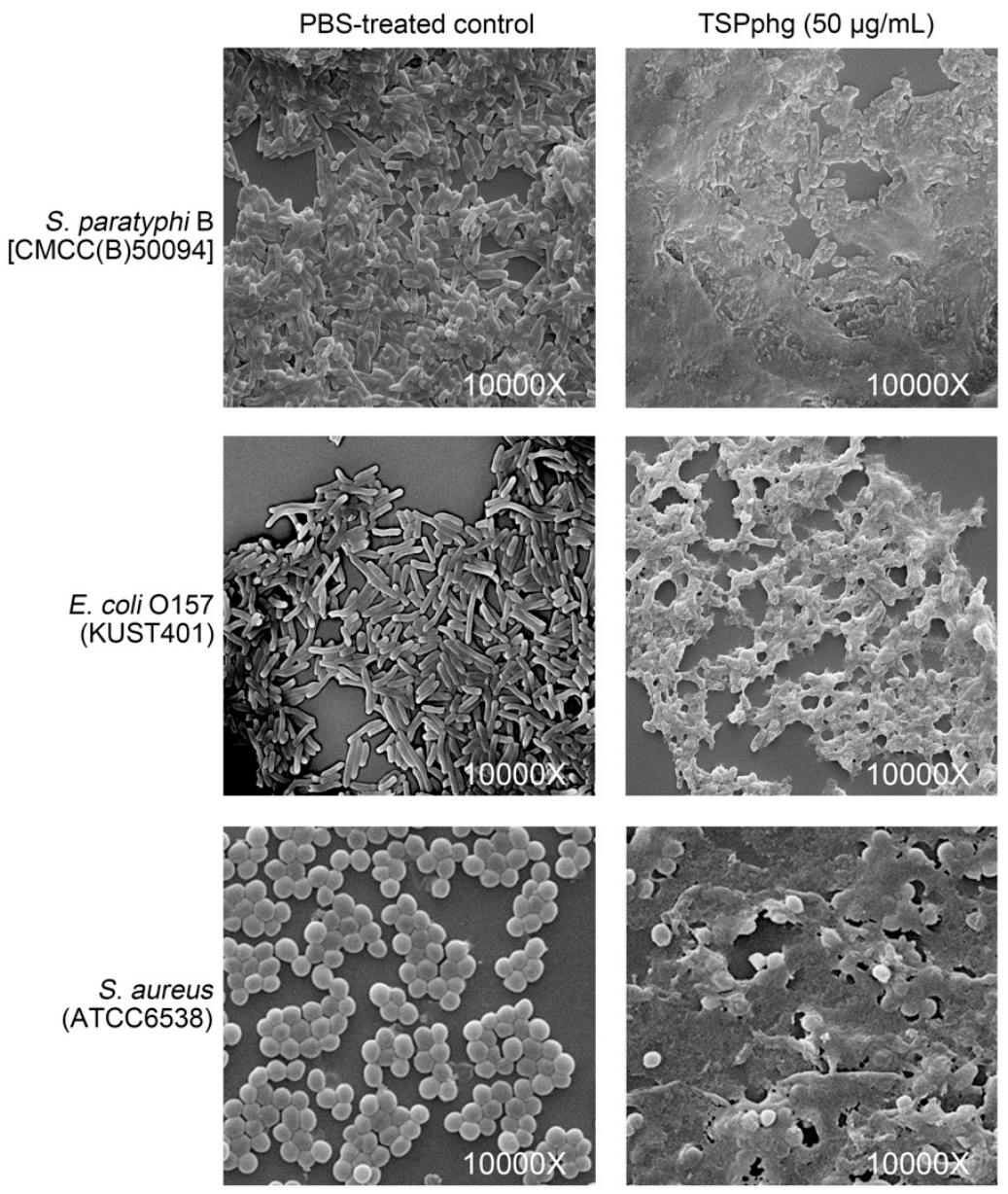

Figure 4. Scanning electron microscopy showing the effects of exogenous TSPphg treatment on the bacterial cell lysis of both Gram-negative (S. paratyphi B and E. coli O157) and Gram-positive (S. aureus) strains. For all tests, the $10^{5} \mathrm{CFU} / \mathrm{mL}$ of bacterial cells was treated with or without $50 \mu \mathrm{g} / \mathrm{mL}$ TSPphg dissolved in $\mathrm{PBS}$ at $37^{\circ} \mathrm{C}$ for $1 \mathrm{~h}$. The magnification is 10,000 times the original size.

\section{Discussion}

The rapid increase in prevalence of antibiotic-resistant strains has encouraged investigations into the role of bacteriophages or their lysins in fighting against bacterial pathogens $[5,12]$. In the present study, we studied a Thermus phage named TSP4 by sequencing its whole genome, and found that the genome of TSP4 consists of 108 protein-coding genes (GenBank number: MH992131.1; Table S1). Interestingly, these protein-coding genes fall into two major categories: genes in the clockwise direction mainly encode phage structural and morphogenesis proteins, while genes in the counterclockwise direction mainly encode DNA replication, recombination, and nucleotide metabolism-related proteins. 
This kind of organization in viruses is special and we speculate that it may help the survival of phage TSP4 under extreme conditions, which deserves further study.

Due to the existence of a protective outer membrane $(\mathrm{OM})$ that usually prevents a great number of antibiotics or drugs from entering Gram-negative bacterial cells, there is an increased interest in the identification and characterization of phage lysins that, as an alternative to conventional antibiotics, combat Gram-negative pathogens [29]. However, currently, the number of reported phage lysins that fight against Gram-positive bacteria is well over those of lysins against Gram-negative bacteria [28]. In this study, we found that TSPphg has considerable antimicrobial activity against both Gram-negative and Gram-positive bacteria; to our knowledge, it represents the first such lysin derived from the natural gene sequence in phage genome. Recently, Plotka et al. have reported an endolysin named Ts 2631 from the Thermus scotoductus phage vB_Tsc2631, which could serve as an agent against alarming MDR Gram-negative bacteria such as MDR clinical strains of A. baumannii and P. aeruginosa [18]. The ability of Ts2631 to pass bacterial OMs and perform cleavage of the peptidoglycan is mediated by its unique 20-residue N-terminus, which contains seven positively charged amino acids [30]. Very similarly, we found that the 20-residue N-terminal tail of TSPphg (MRLPTKTSRFGYVHGQRNNEE) contains six positively charged residues (underlined) as well. Moreover, in silico analysis using SMS v2.0 [31] predicted the isoelectric point of TSPphg to be 9.56. Considering the very short length of the TSPphg protein (166 aa, GenBank number: QAY18185.1), we hypothesize that it may be able to recognize bacteria by electrostatic interactions with negatively charged molecules on the bacterial surface (for example, lipoteichoic acid (LTA) and lipid A in Gram-positive and Gram-negative bacteria, respectively) [32-34]. Very likely, this nonreceptor-mediated mechanism could contribute to penetration of TSPphg through the OMs of Gram-negative bacteria [35,36], and thus be responsible for the observed antimicrobial activity of TSPphg lysin. Overall, these clues suggest that TSPphg could be a multifunctional lysin with bacterial OM-interfering and peptidoglycan-degrading activities. Future structure-based functional studies should delineate the molecular mechanism involved more precisely.

In conclusion, by sequencing and annotating the whole genome of phage TSP4, we characterized a new phage lysin named TSPphg. In vitro and in vivo examination further confirmed its bactericidal activity against both Gram-negative and Gram-positive bacteria. Given the well-presented concerns associated with the emergence and persistence of antibiotic-resistant strains of pathogenic bacteria, TSPphg may yet represent a viable phage-derived alternative to antibiotics.

Supplementary Materials: The following are available online at http://www.mdpi.com/1999-4915/12/2/192/s1, Figure S1: Effects of $\mathrm{pH}$ values (A) and $\mathrm{NaCl}$ concentrations (B) on the lytic activity of TSPphg; Figure S2: Effect of EDTA on the lytic activity of TSPphg; Figure S3: Thermostability of TSPphg. The lysin was first incubated at different temperatures (from 10 to $85^{\circ} \mathrm{C}$ ) for $30 \mathrm{~min}$, and then its activity was determined by the standard turbidity reduction assay against Thermus sp. TC4 cells; Figure S4: Bactericidal activity of TSPphg against different bacteria over a range of concentrations was indicated in terms of $\log _{10}$ reduction; Table S1: Genetic features of open reading frames in the Thermus phage TSP4 genome.

Author Contributions: Conceptualization, X.D. and L.L.; Data curation, F.W. and X.J.; Formal analysis, F.W. and X.J.; Funding acquisition, F.W. and L.L.; Investigation, X.J., Y.Z., B.C., H.L. and F.W.; Methodology, F.W., X.J. and Y.X.; Project administration, F.W.; Software, Q.L.; Supervision, F.W., X.D. and L.L.; Validation, G.Z., J.P. and J.H.; Visualization, F.W. and Q.L.; Writing—original draft, F.W.; Writing—review \& editing, F.W. and L.L. All authors have read and agreed to the published version of the manuscript.

Funding: This study was supported by the Natural Science Foundation of China under Grant No. 31760042 to L.B.L. and No. 31760338 to F.W., the Project of Innovation and Entrepreneurship Training for College Students of Yunnan Province in 2019 under Grant No. 201910674243 to J.N.P., and the Start-up Grant from Kunming University of Science and Technology for the Introduction of Talent Research Project under Grant No. KKSY201626003 to F.W.

Conflicts of Interest: The authors declare no conflict of interest. The funders had no role in the design of the study; in the collection, analyses, or interpretation of data; in the writing of the manuscript, or in the decision to publish the results. 


\section{References}

1. Mwangi, W.; de Figueiredo, P.; Criscitiello, M.F. One health: Addressing global challenges at the nexus of human, animal, and environmental health. PLoS Pathog. 2016, 12, e1005731. [CrossRef] [PubMed]

2. Bordier, M.; Binot, A.; Pauchard, Q.; Nguyen, D.T.; Trung, T.N.; Fortane, N.; Goutard, F.L. Antibiotic resistance in vietnam: Moving towards a one health surveillance system. BMC Public Health 2018, 18, 1136. [CrossRef] [PubMed]

3. Manyi-Loh, C.; Mamphweli, S.; Meyer, E.; Okoh, A. Antibiotic use in agriculture and its consequential resistance in environmental sources: Potential public health implications. Molecules 2018, 23, 795. [CrossRef] [PubMed]

4. Blair, J.M.; Richmond, G.E.; Piddock, L.J. Multidrug efflux pumps in Gram-negative bacteria and their role in antibiotic resistance. Future Microbiol. 2014, 9, 1165-1177. [CrossRef]

5. Abedon, S.T.; Garcia, P.; Mullany, P.; Aminov, R. Editorial: Phage therapy: Past, present and future. Front. Microbiol. 2017, 8, 981. [CrossRef]

6. Abedon, S.T.; Kuhl, S.J.; Blasdel, B.G.; Kutter, E.M. Phage treatment of human infections. Bacteriophage 2011, 1, 66-85. [CrossRef]

7. Barrow, P.; Lovell, M.; Berchieri, A., Jr. Use of lytic bacteriophage for control of experimental Escherichia coli septicemia and meningitis in chickens and calves. Clin. Diagn. Lab. Immunol. 1998, 5, 294-298. [CrossRef]

8. Knoll, B.M.; Mylonakis, E. Antibacterial bioagents based on principles of bacteriophage biology: An overview. Clin. Infect. Dis. 2014, 58, 528-534. [CrossRef]

9. Yang, H.; Yu, J.; Wei, H. Engineered bacteriophage lysins as novel anti-infectives. Front. Microbiol. 2014, 5, 542. [CrossRef]

10. Schuch, R.; Nelson, D.; Fischetti, V.A. A bacteriolytic agent that detects and kills Bacillus anthracis. Nature 2002, 418, 884-889. [CrossRef]

11. Loessner, M.J. Bacteriophage endolysins-Current state of research and applications. Curr. Opin. Microbiol. 2005, 8, 480-487. [CrossRef] [PubMed]

12. Love, M.J.; Bhandari, D.; Dobson, R.C.J.; Billington, C. Potential for bacteriophage endolysins to supplement or replace antibiotics in food production and clinical care. Antibiotics 2018, 7, 17. [CrossRef] [PubMed]

13. Trudil, D. Phage lytic enzymes: A history. Virol. Sin. 2015, 30, 26-32. [CrossRef]

14. Lin, L.; Hong, W.; Ji, X.; Han, J.; Huang, L.; Wei, Y. Isolation and characterization of an extremely long tail Thermus bacteriophage from tengchong hot springs in china. J. Basic Microbiol. 2010, 50, 452-456. [CrossRef] [PubMed]

15. Wang, F.; Ji, X.; Chen, M.; Guo, J.; Deng, X.; Lin, L. Rapid purification of bacteriophage endolysin TSPphg and its exogenous treatment could act as an alternative bacterial cell disruption method. Protein Expr. Purif. 2018, 148, 54-58. [CrossRef] [PubMed]

16. Swift, S.M.; Seal, B.S.; Garrish, J.K.; Oakley, B.B.; Hiett, K.; Yeh, H.-Y.; Woolsey, R.; Schegg, K.M.; Line, J.E.; Donovan, D.M. A thermophilic phage endolysin fusion to a Clostridium perfringens-specific cell wall binding domain creates an anti-clostridium antimicrobial with improved thermostability. Viruses 2015, 7, 3019-3034. [CrossRef]

17. Plotka, M.; Kaczorowska, A.K.; Morzywolek, A.; Makowska, J.; Kozlowski, L.P.; Thorisdottir, A.; Skirnisdottir, S.; Hjorleifsdottir, S.; Fridjonsson, O.H.; Hreggvidsson, G.O.; et al. Biochemical characterization and validation of a catalytic site of a highly thermostable Ts2631 endolysin from the Thermus scotoductus phage vB_Tsc2631. PLoS ONE 2015, 10, e0137374. [CrossRef]

18. Plotka, M.; Kapusta, M.; Dorawa, S.; Kaczorowska, A.K.; Kaczorowski, T. Ts2631 endolysin from the extremophilic Thermus scotoductus bacteriophage vB_Tsc2631 as an antimicrobial agent against Gram-negative multidrug-resistant bacteria. Viruses 2019, 11, 657. [CrossRef]

19. Yang, H.; Wang, M.; Yu, J.; Wei, H. Antibacterial activity of a novel peptide-modified lysin against Acinetobacter baumannii and Pseudomonas aeruginosa. Front. Microbiol. 2015, 6, 1471. [CrossRef]

20. Kugelberg, E.; Norstrom, T.; Petersen, T.K.; Duvold, T.; Andersson, D.I.; Hughes, D. Establishment of a superficial skin infection model in mice by using Staphylococcus aureus and Streptococcus pyogenes. Antimicrob. Agents Chemother. 2005, 49, 3435-3441. [CrossRef] 
21. Pastagia, M.; Euler, C.; Chahales, P.; Fuentes-Duculan, J.; Krueger, J.G.; Fischetti, V.A. A novel chimeric lysin shows superiority to mupirocin for skin decolonization of methicillin-resistant and -sensitive Staphylococcus aureus strains. Antimicrob. Agents Chemother. 2011, 55, 738-744. [CrossRef] [PubMed]

22. Cheng, M.; Zhang, L.; Zhang, H.; Li, X.; Wang, Y.; Xia, F.; Wang, B.; Cai, R.; Guo, Z.; Zhang, Y.; et al. An ointment consisting of the phage lysin LysGH15 and apigenin for decolonization of methicillin-resistant Staphylococcus aureus from skin wounds. Viruses 2018, 10, 244. [CrossRef] [PubMed]

23. Yoong, P.; Schuch, R.; Nelson, D.; Fischetti, V.A. Identification of a broadly active phage lytic enzyme with lethal activity against antibiotic-resistant Enterococcus faecalis and Enterococcus faecium. J. Bacteriol. 2004, 186, 4808-4812. [CrossRef] [PubMed]

24. Larpin, Y.; Oechslin, F.; Moreillon, P.; Resch, G.; Entenza, J.M.; Mancini, S. In vitro characterization of PlyE146, a novel phage lysin that targets Gram-negative bacteria. PLoS ONE 2018, 13, e0192507. [CrossRef] [PubMed]

25. Candan, E.D.; Aksoz, N. Klebsiella pneumoniae: Characteristics of carbapenem resistance and virulence factors. Acta Biochim. Pol. 2015, 62, 867-874. [CrossRef] [PubMed]

26. Martin, R.M.; Bachman, M.A. Colonization, infection, and the accessory genome of Klebsiella pneumoniae. Front. Cell. Infect. Microbiol. 2018, 8, 4. [CrossRef]

27. Wei, J.; Wenjie, Y.; Ping, L.; Na, W.; Haixia, R.; Xuequn, Z. Antibiotic resistance of Klebsiella pneumoniae through beta-arrestin recruitment-induced beta-lactamase signaling pathway. Exp. Ther. Med. 2018, 15, 2247-2254.

28. Maciejewska, B.; Olszak, T.; Drulis-Kawa, Z. Applications of bacteriophages versus phage enzymes to combat and cure bacterial infections: An ambitious and also a realistic application? Appl. Microbiol. Biotechnol. 2018, 102, 2563-2581. [CrossRef]

29. Allen, H.K.; Trachsel, J.; Looft, T.; Casey, T.A. Finding alternatives to antibiotics. Ann. N. Y. Acad. Sci. 2014, 1323, 91-100. [CrossRef]

30. Plotka, M.; Sancho-Vaello, E.; Dorawa, S.; Kaczorowska, A.K.; Kozlowski, L.P.; Kaczorowski, T.; Zeth, K. Structure and function of the Ts2631 endolysin of Thermus scotoductus phage vB_Tsc2631 with unique N-terminal extension used for peptidoglycan binding. Sci. Rep. 2019, 9, 1261. [CrossRef]

31. Stothard, P. The sequence manipulation suite: Javascript programs for analyzing and formatting protein and DNA sequences. Biotechniques 2000, 28, 1102-1104. [CrossRef] [PubMed]

32. Brogden, K.A. Antimicrobial peptides: Pore formers or metabolic inhibitors in bacteria? Nat. Rev. Microbiol. 2005, 3, 238-250. [CrossRef] [PubMed]

33. Mihajlovic, M.; Lazaridis, T. Antimicrobial peptides in toroidal and cylindrical pores. Biochim. Biophys. Acta 2010, 1798, 1485-1493. [CrossRef]

34. Zhang, Y.; Shi, W.; Tang, S.; Li, J.; Yin, S.; Gao, X.; Wang, L.; Zou, L.; Zhao, J.; Huang, Y.; et al. The influence of cathelicidin LL37 in human anti-neutrophils cytoplasmic antibody (anca)-associated vasculitis. Arthritis Res. Ther. 2013, 15, R161. [CrossRef] [PubMed]

35. Briers, Y.; Lavigne, R. Breaking barriers: Expansion of the use of endolysins as novel antibacterials against Gram-negative bacteria. Future Microbiol. 2015, 10, 377-390. [CrossRef] [PubMed]

36. Deslouches, B.; Steckbeck, J.D.; Craigo, J.K.; Doi, Y.; Burns, J.L.; Montelaro, R.C. Engineered cationic antimicrobial peptides to overcome multidrug resistance by ESKAPE pathogens. Antimicrob. Agents Chemother. 2015, 59, 1329-1333. [CrossRef] [PubMed]

(C) 2020 by the authors. Licensee MDPI, Basel, Switzerland. This article is an open access article distributed under the terms and conditions of the Creative Commons Attribution (CC BY) license (http://creativecommons.org/licenses/by/4.0/). 